\title{
Deviasi Kata dan Perubahan Makna Bahasa pada Sosial Media Facebook
}

\author{
Mulasih \\ Universitas Peradaban Bumiayu \\ email: mulasihtary@peradaban.ac.id \\ Yukhsan Wakhyudi \\ Universitas Peradaban Bumiayu \\ email: yukhsanwakhyudi@peradaban.ac.id
}

\begin{abstract}
Abstrak
Tujuan penelitian ini adalah pertama, mendeskripsikan deviasi kata yang terdapat pada ragam bahasa media sosial facebook. Kedua, mendeskripsikan perubahan makna pada ragam bahasa media sosial facebook. Penelitian ini merupakan penelitian deskriptif kualitatif karena dua alasan. Pertama, masalah yang akan diteliti, diamati dengan cermat dideskripsikan kemudian disimpulkan. Penelitian ini bertujuan membuat deskripsi, gambaran, lukisan secara sistematis, faktual, dan akurat mengenai data, sifat-sifat serta hubungan fenomena yang diteliti. Kedua, penelitian ini termasuk penelitian deskiptif kualitatif, yaitu penelitian yang dilakukan dengan menguraikan atau mendeskripsikan serta memaparkan data kemudian dilanjut dengan penganalisisan deviasi kata, proses deviasi kata dan penggunaanya dalam facebook. Hasil penelitian ini adalah deviasi (penyimpangan) bahasa yang marak terjadi dan berkembang pesat di kalangan remaja facebooker. Meski bahasa ini, tidak ada di dalam ejaan yang disempurnakan dalam bahasa Indonesia (PUEBI), tetapi mereka dengan leluasa memakai bahasa alay ini dalam dunia mereka sendiri. Deviasi katanya banyak terjadi dari aspek pengurangan dan penambahan pada kata aslinya, sehingga kata baru yang terbentuk tidak terdapat dalam bahasa Indonesia. Pembentukan katanya bersifat berlebihan dan mengandung perubahan asosiasi makna yang mengandung kelucuan.
\end{abstract}

Kata kunci: deviasi kata, perubahan makna bahasa, sosial media facebook.

\begin{abstract}
The purpose of this study is first, to describe the word deviation contained in the various languages of social media Facebook. Second, describe changes in meaning in the various languages of Facebook social media. This research is a qualitative descriptive study for two reasons. First, the problems to be examined, carefully observed are described later concluded. This study aims to make a description, description, painting systematically, factually, and accurately regarding the data, the characteristics and relationships of the phenomena studied. Second, this study includes deskiptif qualitative research, namely research carried out by describing or describing and describing the data then continued by analyzing word deviation, word deviation process and its use on Facebook. The results of this study are language deviations which are prevalent and are rapidly developing among teenage facebookers. Although this language, it is not in the spelling that is perfected in Indonesian (PUEBI), but they freely use this language in their own world. The word deviation occurs a lot from the aspect of reduction and addition to the original word, so that the new words formed do not exist in Indonesian. The word formation is excessive and contains changes in meaning associations that contain humor.
\end{abstract}

Keywords: word deviation, changes in the meaning of language, social media facebook. 
Mulasih, Yukhsan Wakhyudi

\section{Pendahuluan}

Manusia adalah makhluk sosial yang akan selalu menjalin komunikasi manusia dalam kehidupan bermasyarakat. Manusia akan terus berinteraksi dalam berbagai sitausi dengan perantara media komunikasi lainnya. Sejak berkembangnya teknologi informasi, yang dimulai dengan munculnya internet, manusia menemukan cara baru berkomunikasi jarak jauh dan menciptakan sajian informasi dengan mudah. Saat awal-awal berkembangnya, teknologi internet merupakan teknologi yang dirasakan berperan signifikan dalam berinteraksi antar manusia. Dengan masifnya perkembangan internet teknologi, terdapat suatu fenomena yang cukup menarik, yang masih digunakan sebagai media komunikasi, yaitu situs Media sosial facebook.

Media sosial (medsos) salah satunya facebook adalah jalur cepat untuk mempunyai banyak teman di dunia maya. Dari medsos ini kita bisa melihat foto dan data-data pribadi teman sekaligus memberi komentar dan bertukar via inbok/masseger. Tampaknya tren pertemanan seperti itu semakin diminati, seiring meningkatnya pengguna internet dan android itu sendiri. Dari mulai anak kecil, mahasiswa, sampai orang tua kini mulai ramai mendatangi warung-warung internet. Mereka rela menghabiskan uang hanya untuk mempunyai account facebook saja. Rasanya aneh dan terkesan kampungan jika saat ini kita tidak mempunyai account facebook, seperti itu mungkin pandangan mereka jika tidak mempunyai account di situs Media sosial itu

Dari pemaparan tersebut kita dapat mengetahui bahwa perkembangan teknologi dan budaya facebook saat ini sangat berpengaruh dalam kehidupan masyarakat sehari-hari, terutama dalam kehidupan serta pergaulan remaja. Di ruang facebook pengguna internet menggunakan komunikasi dengan bahasa tulis. Bahasa tulis yang digunakan memiliki karakter sendiri, yaitu berupa bahasa gaul yang memiliki banyak deviasi dalam kata yang berimplikasi pada terjadinya perubahan makna. Penggunaan bahasa seperti ini tidak hanya terjadi pada saat berkomunikasi dengan facebook saja, tetapi juga dalam shoOrt message send (sms). Dalam penggunaannya, bahasa facebook pada dasarnya tidak ada batasan dalam penggunaan kata atau karakter huruf. Akan tetapi, saat ini banyak sekali dijumpai orang yang mempunyai account facebook yang menggunakan bahasa gaul atau alay (anak layangan). Bahasa gaul merupakan bahasa anak-anak remaja gaul yang biasa digunakan sebagai bahasa sandi. Bahasa ini mulai dikenal dan digunakan sekitar tahun 1970. Awalnya, bahasa ini dikenal sebagai "bahasanya anak jalanan" karena biasanya digunakan oleh para anak jalanan, sebagai kata sandi yang hanya dimengerti oleh kelompok mereka sendiri.

Belakangan bahasa ini menjadi populer dan banyak digunakan dalam percakapan sehari-hari. Selain karena sering digunakan oleh para remaja untuk menyampaikan suatu hal secara rahasia (tanpa diketahui guru dan orang tua mereka), juga banyaknya media (televisi, radio, film, majalah, dan lain-lain) yang menggunakan kata-kata itu, sehingga bahasa gaul menjadi sangat populer. Bahasa gaul atau bahasa prokem terus berkembang dari masa ke masa. Ada sebagian kata yang diperkenalkan sejak tahun 1970an dan hingga kini masih sering dipakai. Namun, tidak sedikit kata-kata itu sudah tidak dikenal lagi dan berganti dengan istilah lain yang lebih "funky".

Munculnya bahasa "alay" di kalangan remaja dengan semakin berkembangnya teknologi, terutama berkembangnya situs Media sosial, seperti facebook, kemunculannya dapat dikatakan fenomenal, 
karena cukup menyita perhatian. Bahasa baru ini seolah menggeser penggunaan bahasa Indonesia dikalangan segelintir remaja. Bahasa alay itu adalah variasi bahasa yang muncul karena adanya komunitas anak-anak remaja/muda. Alay adalah singkatan dari anak layangan, alah lebay, anak layu, atau anak kelayapan yang menghubungkannya dengan anak jarpul (jarang pulang). Akan tetapi yang paling terkenal adalah anak layangan. Dominannya, istilah ini menggambarkan anak yang menganggap dirinya keren secara gaya bahasanya dan busananya.

Menurut Koentjaraningrat, alay adalah gejala yang dialami pemuda dan pemudi bangsa Indonesia, yang ingin diakui statusnya di antara teman-temannya. Gejala ini akan mengubah gaya tulisan, dan gaya berpakaian mereka. Istilah alay hadir setelah di facebook semakin marak penggunaan bahasa tulis yang tak sesuai kaidah bahasa Indonesia oleh remaja. Hingga kini belum ada definisi yang pasti tentang istilah ini, namun bahasa ini kerap dipakai untuk menunjuk bahasa tulis. Dalam bahasa alay bukan hanya bunyi yang dipentingkan tapi juga variasi tulisan. Pada dasarnya ada dua hal utama yang menjadi perhatian remaja, yaitu identitas dan pengakuan.

Penulisan bahasa dengan ciri khasnya bisa jadi pembentukan kedua hal di atas. Ada dua hal alasan utama remaja menggunakan bahasa tulis dengan ciri tersendiri (alay). Lebih lanjut, Koentjaraningrat berkomentar, "Pertama, mereka mengukuhkan diri sebagai kelompok sosial tertentu, yaitu remaja. Yang kedua, ini merupakan sebuah bentuk perlawanan terhadap dominasi bahasa baku atau kaidah bahasa yang telah mapan," jelasnya. Maknanya, remaja merasa menciptakan identitas dari bahasa yang mereka ciptakan sendiri pula. Remaja sebagai kelompok usia yang sedang mencari identitas diri memiliki kekhasan dalam menggunakan bahasa tulis di facebook. Ada semacam keseragaman gaya yang kemudian menjadi gaya hidup (lifestyle) mereka.

Remaja yang masih labil dan gemar meniru, sangat mudah tertular dan memilih menggunakan bahasa ini daripada menggunakan Bahasa Indonesia yang baik dan benar. Apalagi ada anggapan bahwa bahasa ini adalah bahasa gaul, sehingga orang yang tidak menggunakannya akan dianggap ketinggalan jaman atau kuno. Dari hal tersebut peneliti akan mengkaji aspek deviasi (penyimpangan) kata dan perubahan makna pada penggunaan bahasa di facebook.

Sementara itu, dalam teori bahasa adalah banyak cabang ilmu dapat digunakan dalam menganalisis persoalan bahasa dan kesalahan-kesalahannya. Morfologi adalah ilmu cabang tatabahasa yang membicarakan hubungan gramatikal antara bagian-bagian intern kata, dan yang membicarakan morfem serta bagaimana morfem itu dibentuk menjadi kata (Badudu, 1983: 5). Kata adalah yang menjadi objek daripada morfologi, dalam sebuah kata khusunya facebook banyak terjadi perubahan-perubahan kata. Kemudian perubahan-perubahan bentuk kata tersebut yang menyebabkan perubahan jenis dan makna kata. Oleh karena itu, morfologi di samping bidang utamaya mempelajari seluk beluk kata. Akan tetapi, mempelajari kemungkinan adanya perubahan jenis makna kata yang timbul akibat perubahan bentuk kata.

Sedangkan proses morfologis ialah cara pembentukan kata-kata dengan menghubungkan morfem yang satu dengan yang lain (Samsuri, 1982:190). Lebih jelas, proses morfologis ialah proses pembentukan kata-kata dari satuan lain yang merupakan bentuk dasarnya (Ramlan, 1983). Salah satu proses morfologis adalah 
Mulasih, Yukhsan Wakhyudi

suplisi (penggantian) atau proses perubahan yang menimbulkan perubahan bentuk yang sama sekali baru.

Semantik di dalam bahasa Indonesia berasal dari bahasa inggris yaitu semantics dan dari bahasa yunani sema (nomina) 'tanda'. Jadi semantik adalah ilmu yang mempelajari tentang makna atau makna (Djajasudarma, 2008:1). Ada pula yang menyatakan semantik merupakan salah satu komponen dari tata bahasa (dua komponen lain adalah sintaksis dan fonologi) dan makna sebuah kalimat sangat ditentukan oleh semantik (Chaer, 2007: 285).

Dalam perubahan makna selalu ada hubungan (asosiasi) antara makna lama dan makna baru, tidak peduli apapun yang menyebabkan perubahan itu terjadi. Dalam beberapa hal, asosiasi bisa begitu kuat untuk mengubah makna dengan sendirinya, sebagian lagi asosiasi itu hanyalah suatu wahana untuk suatu perubahan yang ditentukan oleh sebab-sebab lain tetapi bagaimanapun suatu jenis asosiasi akan selalu mengalami proses. Dalam pengertian ini asosiasi dapat dianggap sebagai suatu syarat mutlak bagi perubahan makna (Stephen, 2007 : 263264).

Beberapa dari ahli semantik awal mengakui suatu asosiasinisme yang sederhana, mereka mencoba menjelaskan perubahan makna sebagai hasil asosiasi antara kata-kata yang diisolasikan (berdiri sendiri). Makna asosiasi sendiri adalah makna yang dimiliki oleh sebuah leksem atau kata berkenaan dengan adanya hubungan kata sesuatu yang luar bahasa. Misalnya kata melati diasosiasikan dengan 'sesuatu yang suci atau kesucian' makna asosiasi ini sebenarnya sama dengan lambang atau perlambang yang digunakan oleh suatu masyarakat bahasa untuk menyatakan konsep lain yang mempunyai kemiripan dengan sifat, keadaan atau ciri yang ada pada konsep asal kata atau leksem tersebut (Chaer: 2007: 293).

Sedangkan makna konseptual adalah makna yang dimiliki oleh sebuah leksem terlepas dari konteks atau asosiasi apapun misalnya kata kuda memiliki makna konseptual 'sejenis binatang berkaki empat yang bisa dikendarai' makna konseptual ini sebenarnya sama saja dengan makna leksikal, makna denotative dan makna referensial (Chaer, 2007:293).

Bahasa tidak bisa terpisah dari kehidupan manusia karena bahasa adalah alat komunikasi antara anggota masyarakat berupa simbol bunyi yang dihasilkan oleh alat ucap manusia (Keraf, 2011: 1). Sebagian bahasa yang digunakan di facebook adalah ragam bahasa gaul, karena sebagian besar pengguna facebook adalah dari kalangan anak muda/remaja yang ingin diakui statusnya. Mereka menciptakan bahasa sendiri yang menurut mereka merupakan bahasa 'rahasia' dan hanya berlaku bagi kelompok mereka sendiri yaitu remaja. Gejala ini akan mengubah gaya penulisan serta komunikasi secara lisan. Bahasa gaul adalah 'kreativitas' ragam seperti itu jangan hanya dilihat dari segi linguistik saja melainkan dilihat dari segi sosialnya juga.

Kemunculan kata-kata baru dalam ragam bahasa tersebut. Menambah kekayaan perbendaharaan kata. Setidaknya untuk kalangan remaja. Kreativitas ini barangkali mengarah kepada ragam bahasa yang menggelitik telinga orang yang membaca dan mendengarnya.

Tujuan penelitian ini adalah pertama, mendeskripsikan deviasi kata yang terdapat pada ragam bahasa media sosial facebook. Kedua, mendeskripsikan perubahan makna pada ragam bahasa media sosial facebook. 


\section{Metode Penelitian}

Penelitian ini merupakan penelitian deskriptif kualitatif karena dua alasan. Pertama, masalah yang akan diteliti, diamati dengan cermat dideskripsikan kemudian disimpulkan. Penelitian ini bertujuan membuat deskripsi, gambaran, lukisan secara sistematis, faktual, dan akurat mengenai data, sifat-sifat serta hubungan fenomena yang diteliti. Kedua, penelitian ini termasuk penelitian deskiptif kualitatif, yaitu penelitian yang dilakukan dengan menguraikan atau mendeskripsikan serta memaparkan data kemudian dilanjut dengan penganalisisan deviasi kata, proses deviasi kata dan penggunaanya dalam facebook.

Data merupakan keterangan nyata yang digunakan dalam kajian penelitian. Data dalam penelitian ini berupa deviasi kata yang digunakan dalam ragam bahasa facebook. Sumber data adalah subjek dari mana data dapat diperoleh. Sumber data yang dipakai dalam penelitian ini adalah para pemilik facebook yang berstatus pelajar, pemilik facebook berstatus mahasiswa.

\section{Hasil dan Pembahasan \\ Deviasi Kata dan Perubahan Makna pada Ragam Bahasa Media Sosial Facebook}

\section{Kata Benda}

a.Kata uank yang merubakan perubahan dari kata uang, yang menunjukkan makna alat pembayaran yang sah yang dikeluarkan oleh pemerintah. Uank dengan uang maknanya sama, tetapi bentuk tulisannya berbeda (homofon). Makna asosiasi yang terbentuk, uang bersifat formal, sedangkan mengandung asosiasi kelucuan karena pemlesetan dari bentuk tulisannya. b. Kata utak perubahan dari kata otak, yang menunjukkan makna alat dalam tubuh yang digunakan untuk berfikir. Di sini kedua kata itu maknanya masih tetap sama, tetapi tulisannya sudah berubah dari kata otak menjadi utak. Makna asosiasi yang terbentuk mengandung asosiasi kelucuan karena pemlesetan dari bentuk tulisannya.

c. Phutu perubahan dari kata photo yang memiliki bentuk kata dan makna yang berbeda. Kata phutu (dalam bahasa Jawa bermakna cucu), sedangkan photo (gambar). Akan tetapi, pengguna facebook yang mayoritas remaja menyebut kata photo menjadi phutu. Makna asosiasi yang terbentuk mengandung asosiasi kelucuan karena pemlesetan dari bentuk tulisannya, sehingga sekalipun phutu bermakna photo, tetapi ada kesan asosiasi sebagai 'cucu" atau mungkin "makanan".

d. Kata tuami merupakan perubahan dari kata suami, yang menujukkan makna pria yang menjadi pasangan istri. Kata suami telah berubah tulisan dan bunyinya menjadi tuami, tetapi maknanya tetap suami. Makna asosiasi yang terbentuk, mengandung asosiasi kelucuan karena pemlesetan dari bentuk tulisannya dengan pelafalan yang terkesan unik juga.

e.Kata pacal merupakan perubahan dari kata pacar, yang menunjukkan makna seorang kekasih. Akan tetapi, kata pacal dengan pacar memiliki bentuk tulisan yang berbeda. Sedangkan pacal dalam kamus bahasa Indonesia memiliki makna "sejenis ikan kaka air tawar", sedangkan pacar adalah "kekasih" akan tetapi kedua kata ini 
Mulasih, Yukhsan Wakhyudi

disamakan karena adanya makna asosiasi yang terbentuk, mengandung asosiasi kelucuan karena pemlesetan dari bentuk tulisannya, yang seakan pacal adalah bentuk pengucapan cedal dari kata pacar.

f. Kata lumah yang merupakan perubahan dari kata rumah, yang menunjukkan makna bangunan untuk tempat tinggal. Kata lumah dan rumah sudah berubah bentuk tulisannya dan katanya. sedangkan kata lumah dalam kamus bahasa Indonesia tidak memiliki makna, sehingga kata lumah adalah pemlesetan dari bentuk rumah, dengan intonasi yang di-cedal-kan dengan tujuan untuk mendapatkan efek dan asosiasi makna kelucuan.

g.Kata onyet yang merupakan perubahan dari kata monyet, yang menunjukkan makna binatang yang memiliki bulu keabu-abuan dan memiliki ekor panjang. Kata monyet berubah bentuknya tulisannya menjadi onyet dengan menghilangkan huruf $m$. Onyet sendiri dalam kamus bahasa Indonesia tidak memiliki makna, sehingga onyet adalah bahasa gaul yang terjadi karena penghilangan huruf $m$. Tujuannya adalah untuk menciptakan kesan kelucuan.

\section{Kata Kerja}

a. Kata colat merupakan perubahan dari kata sholat. Kata sholat berasal dari bahasa Arab yang memiliki makna ibadah menyembah sang pencipta. Kata sholat berubah bentuk tulisannya menjadi colat, tetapi memiliki makna yang sama. Yang terjadi adalah perubahan huruf yang diciptakan untuk menimbulkan asisiasi kelucuan. b. Kata naek merupakan perubahan dari kata naik yang menunjukkan makna bergerak ke atas. Kata naik berubah menjadi naek. Berubah dari bentuk tulisannya juga bunyinya. Akan tetapi, maknanya tetap sama, perubahan huruf ini sebagai cara untuk menciptakan kesan makna yang lucu.

c. Kata moyoy yang merupakan perubahan dari kata molor yang menunjukkan makna melakukan pekerjaan tidur. Kata molor berubah bentuk tulisannya menjadi moyoy untuk menciptakan kesan dan makna yang mengasosiasikan hal yang lucu.

d. Kata inend yang merupakan perubahan dari kata ingin yang memiliki makna berharap, bercita-cita hendak. Kedua kata itu memiliki satu makna, tetapi mengalami perubahan bentuk yang berbeda. Perubahan penulisan atau huruf ini untuk mengasosiasikan kesan kelucuan.

\section{Kata Sifat}

a. Kata cebel merupakan perubahan dari kata sebalyang memiliki makna mendongkol, kesal, jengkel. Kata sebal mengalami perubahan bentuk baru yaitu cebel, kata cebel sendiri dalam kamus bahasa Indonesia tidak memiliki makna. Perubahan bentuk atau huruf ini terjadi untuk mengasosiasikan kesan kelucuan.

b. Kata binund yang merupakan perubahan dari kata bingung yang memiliki makna merasa kurang paham atau kurang jelas. Kata bingung mengalami perubahan bentuk menjadi binund. Kata binund ini tidak memiliki makna dalam bahasa Indonesia, sehingga kata binund ini bertujuan untuk menciptakan kesan atau asosiasi unik dan kelucuaan dalam bahasa gaul. 
c. Kata cakit yang merupakan perubahan dari kata sakit memiliki makna, yaitu berasa tidak enak dibagian tubuh karena sesuatu. Kata sakit mengalami perubahan bentuk menjadi cakit. Kata cakit tidak ada dalam bahasa Indonesia. Kata cakit dibentuk dari pergantian huruf $s$ menjadi $c$ yang bertujuan untuk mengasosiasikan kelucuan dalam ragam bahasa gaul.

d. Kata pucink merupakan perubahan dari kata pusing yang memiliki makna sakit kepala. Keduanya memiliki makna yang sama dan mengalami perubahan bentuk dari pusing menjadi pucink. Kata pucink tidak ada dalam bahasa Indonesia, kata pucink adalah kreasi dari bahasa gaul yang bertujuan untuk menciptakan kesan kelucuan.

e. Kata dolo merupakan perubahan dari kata dahulu yang memiliki makna masa lampau. Mengalami perubahan bentuk dari dahulu menjadi dolo, tetapi maknanya tetap sama. Kata dolo tidak ada dalam bahasa Indonesia, sehingga kata dolo merupakan bentuk kreasi bahasa gaul untuk menciptakan asosiasi kelucuan.

f. Kata phuyenk merupakan perubahan dari kata puyeng yang memiliki makna sakit kepala. Kata phuyenk mengalami perubahan bentuk dari puyeng. Kata phuyenk tidak terdapat dalam bahasa Indonesia, sehingga merupakan bentuk pemlesetan yang bertujuan untuk menciptakan asosiasi kelucuan.

g. Kata aseg merupakan perubahan dari kata asik yang memiliki makna menyenangkan. Kata asep mengalami perubahn bentuk dari asik. Kata aseg tidak ada dalam bahasa Indonesia, sehingga kata aseg merupakan penciptaan baru yang berasal dari kata asik, yang mengesankan asosiasi makna kelucuan.

h. Frasa kicauw balauw merupakan perubahan dari kata kacau balau yang memiliki makna campur aduk sehingga tidak dapat dibedakan lagi. Frasa kicauw balauw mengalami perubahan bentuk dari kacau balau yang memiliki makna sama, tetapi mengecankan kelucuan karena kata kicauw seperti anamatope suara burung.

i. Kata kanend merupakan perubahan dari kata kangen yang memiliki makna rindu rasa ingin bertemu, yang mengalami perubahan bentuk dari kangen menjadi kanend. Kata kanend tidak terdapat dalam bahasa Indonesia, merupakan hasil kreativitas berbahasa dalam memplesetkan kata kangen, sehingga menciptakan kesan kelucuan.

j. Kata cemungud merupakan perubahan dari kata semangat yang memiliki makna kekuatan batin. Kata cemungud mengalami perubahan bentuk dari kata semangat. Kata cemungud tidak ada dalam bahasa Indonesia sehingga merupakan bentuk kreativitas berbahasa yang menciptakan perubahan makna asosiasi kelucuan dari kata awalnya.

k. Kata agimerupakan perubahan dari kata lagi yang memiliki makna tambah atau sedang melakukan sesuatu. Kata agi mengalami perubahan bentuk dari kata lagiyang terjadi karena penghilangan huruf awal I. Kata agi tidak ada dalam bahasa Indonesia sehingga mengesankan kelucuan seperti kata agi dalam bahasa Jawa. 
Mulasih, Yukhsan Wakhyudi

\section{Kata Ganti}

a. Kata saia merupakan perubahan dari kata saya yang memiliki makna aku. Kata saia mengalami perubahan bentuk tulisan dari saya. Kata saia tidak ada dalam Indonesia, perubahan makna yang tercipta mengesankan makna kelucuan.

b. Engkauw merupakan perubahan dari kata engkau memiliki makna kamu. Mengalami perubahan bentuk dari kata engkau menjadi engkauw dari asepk perubahan huruf dan bunyinya, sehingga dengan kata engkauw mengesankan pelafalan bunyi yang berlebihan. Perubahan asosian makna yang terjadi engkauw terkesan lucu dan berlebih-lebihan.

c. Kata kamyu merupakan perubahan dari kata kamu yang memliki makna kata ganti orang kedua. Kata kamyu mengalami perubahan bentuk penulisan dan bunyi dari kata kamu. Perubahan asosiasi makna yang terbentuk kata kamyu mengesankan kelucuan dalam ragam bahasa gaul karena kata kamyu tidak ada dalam bahasa Indonesia.

d. Kata akuwh merupakan perubahan dari kata aku yang memiliki makna aku sebagai kata ganti orang pertama tungga. Kata akuwh mengalami perubahan bentuk dari aku, untuk mengesankan perubahan makna yang berlebihan, sehingga mengesankan asosiasi makna yang mengandung kelucuan.

e. Kata quw merupakan perubahan dari kata aku yang memiliki makna aku sebagai kata ganti orang pertama tungga. Kata quw mengalami perubahan bentuk dari aku, yang mengesankan asosiasi makna yang berlebihan, teruatama dalam pengucapannya. Tujuannya untuk menciptakan asosiasi kelucuan dalam ragam bahasa gaul.

\section{Kesimpulan}

Situs Media sosial dalam internet salah satunya seperti facebook adalah jalur tepat untuk mempunyai banyak teman di dunia maya. Dari situs ini kita bisa melihat foto dan data-data pribadi teman sekaligus memberi komentar dan bertukar via pesan. Remaja saat ini sindrom bahasa alay. Hal ini sangat kentara dan banyak berserakan dalam Media dunia facebook.

Bahasa alay belakangan ini menjadi populer dan banyak digunakan dalam percakapan sehari-hari. Selain karena sering digunakan oleh para remaja untuk menyampaikan suatu hal secara rahasia (tanpa diketahui guru dan orang tua mereka), juga banyaknya media (televisi, radio, film, majalah, dan lain-lain) yang menggunakan kata-kata itu, sehingga bahasa gaul menjadi sangat populer. Bahasa gaul atau bahasa prokem terus berkembang dari masa ke masa. Ada sebagian kata yang diperkenalkan sejak tahun 1970-an dan hingga kini masih sering dipakai. Namun, tidak sedikit kata-kata itu sudah tidak dikenal lagi dan berganti dengan istilah lain yang lebih "funky".

Maka dari itu, simpulan dalam analisis sederhana ini, bahasa alay merupakan deviasi (penyimpangan) bahasa yang marak terjadi dan berkembang pesat dikalangan remaja facebooker. Meski bahasa ini, tidak ada didalam ejaan yang disempurnakan dalam bahasa Indonesia, tetapi mereka dengan leluasa memakai bahasa alay ini dalam dunia mereka sendiri. Deviasi katanya banyak terjadi dari aspek penguran dan penambahan pada kata aslinya, sehingga kata baru yang terbentuk tidak terdapat dalam bahasa Indonesia. Pembentukan katanya bersifat berlebihan dan mengandung perubahan asosiasi makna yang mengandung kelucuan. 


\section{DAFTAR PUSTAKA}

Chaer, Abdul. 2002. Pengantar Semantik Bahasa Indonesia. Jakarta : Rineka Cipta. Kridalaksana, Harimurti.1996. Pembentukan Kata Dallam Bahasa Indonesia. Jakarta: Gramedia Pustaka Utama.

Kridalaksana, Harimurti. 2001. Kamus Linguistik. Jakarta: Gramedia Pustaka Utama.

Koenjraningrat,2005, Pengantar Antropologi. Jakarta: Rineka Cipta

Pateda, Mansoer. 1996. Semantik Leksikal. Jakarta: Rineka Cipta.

Robins. 1992. Linguistik Umum, Yogjakarta : Penerbit Kanisus.

Samsuri, 1981. Analisis Bahasa. Jakarta Pusat: Erlangga.

Sumarsono. 2002. Sosiolinguistik. Yogyakarta : Pustaka Pelajar.

Tugiarti, Tutut. 2008. Morfologi Bahasa Indonesia. Purwokerto: Universitas Muhammadiyah Purwokerto.

Ullman, Stephen. 2009. Pengantar Semantik. Yogjakarta : Pustaka Pelajar. 